\begin{tabular}{|c|}
\hline 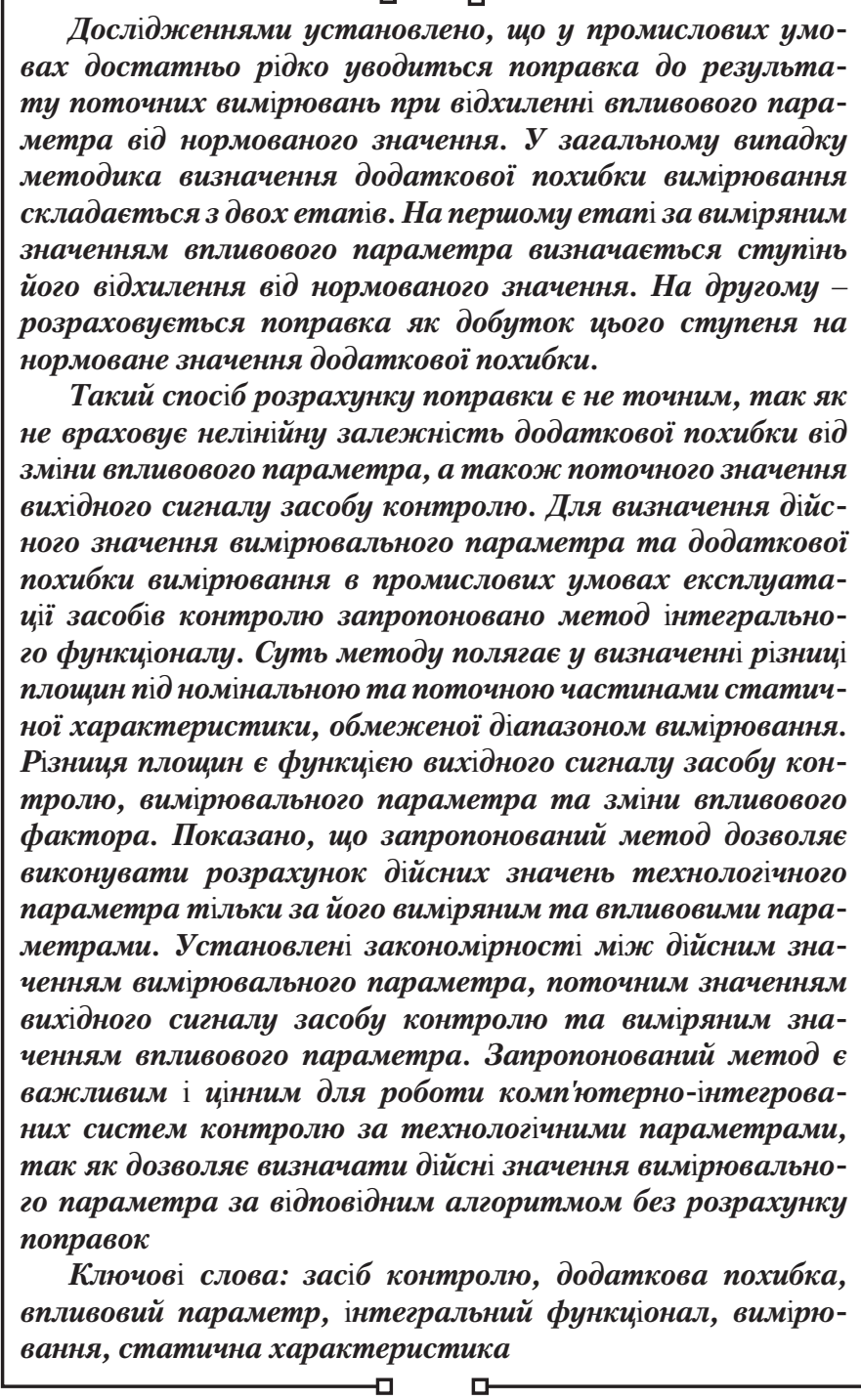 \\
\hline
\end{tabular}

UDC 532.135.66.012

DOI: $10.15587 / 1729-4061.2019 .171445$

\section{STUDYING ADDITIONAL MEASUREMENT ERRORS FROM CONTROL TOOLS USING AN INTEGRAL FUNCTIONAL METHOD}

Y. Stentsel

Doctor of Technical Sciences, Professor, Head of Department*

E-mail: kafedrakisu@gmail.com

O. Pork u i a n

Doctor of Technical Sciences, Professor*

E-mail: kafedrakisu@gmail.com

K. Litvinov

$\mathrm{PhD}$, Senior Lecturer* E-mail:snu.rada@gmail.com

T. Sot nikova

PhD, Associate Professor*

E-mail: tatiana.sotnikova1005@gmail.com *Department of Computer-Integrated

Management Systems

Volodymyr Dahl East Ukrainian National University

Tsentralnyi ave., 59-a,

Severodonetsk, Ukraine, 93400

\section{Introduction}

The efficiency of technological processes is defined by the precision in maintaining technological parameters at the assigned level, which is standardized by respective regulations. To meet this requirement, technological parameters are subject to control by using technical tools. The latter transmit the result from measurements in the form of an output signal for visualization, for example, by a real-time monitor at a computer-integrated control system. The output signal from such tools is standardized at the stage of industrial execution by establishing a range of measurement and an accuracy class. In addition, documentation on technical means specifies additional measurement errors (AME) that are caused by deviations of influencing parameters from the rated values. The basic influencing parameters typically include the ambient temperature, atmospheric pressure, air humidity, supplied voltage, current frequency, and some others. At constant measured parameter, the output signal from a control tool varies towards larger or lower values by a certain magnitude due to the deviation of an influencing parameter from the rated value. Thus, a change in output signal is a function of the change in the influencing parameter. The working range of change in the basic influencing parameters is specified in the technical documentation for a control tool, while AME only for a certain change in it.

Research has found that the dependence of AME on deviation in an influencing parameter on the rated value in a general case is nonlinear, which increases with an increase in the coefficient sensitivity along the channel of this parameter's effect. In addition, it was established that at an increase in the influencing parameter from the rated, the AME value is considerably less than when it decreases by the same magnitude. In this case, there is an increase in the non-linearity of AME dependence on a decrease in the influencing parameter. Under conditions of industrial operation, control tools generate an output signal, which is used, at inverse calibration, to obtain the value for a technological parameter. Since the primary measuring converter is affected by both internal and external influencing parameters, then the output signal does not match the actual value for a measured technological parameter, but it is offset by the AME magnitude. As the actual value for a measured technological parameter is accepted to be the reading from a control tool based on its graded scale, then, in this case, AME is not taken into consideration, which is predetermined by some influencing parameter. Therefore, the operators always face the task on determining this error with the greatest precision in order 
to introduce the corresponding correction to the measurement result. Currently, AME is typically determined by two methods. The most accurate is the method of comparison with the metric at which a working control tool is under real operating conditions, while the reference one under conditions of calibrating the working one. The second method is the estimation, based on determining AME based on the measured value for a current influencing parameter at a known conversion coefficient along the channel of its effect. Typically, this method is approximate and does not take into consideration the character of AME distribution both over the measurement range of a technological parameter and based on a change in the influencing parameter. As the operation of control tools at an industrial facility does not involve metrics and reference means, then, as a rule, the second method for determining AME is applied. In most cases, the second method is used to rate AME for the normative-technical documentation on a control tool. It implies that the technical conditions specify AME, which is predetermined at a deviation of the influencing parameter by a certain rated variable, for example, at a deviation of temperature for every $10{ }^{\circ} \mathrm{C}$ from the normal flat $(20 \pm 5){ }^{\circ} \mathrm{C}$. If the working range of change in an influencing parameter is large enough, for example, for a temperature change from minus $40{ }^{\circ} \mathrm{C}$ to plus $120^{\circ} \mathrm{C}$, then the temperature of AME dependence on the deviation in temperature for every $10{ }^{\circ} \mathrm{C}$ is nonlinear. That leads to that the correction to a measurement result is determined with an error, which may exceed its value. In this case, the calculated actual value for a measured parameter (AVMP) is underestimated (or overestimated), which leads to the incorrect assessment of the quality of a produced article or the operation of an automated control system. Thus, the relevance of this work is in the construction of a method, which would make it possible to determine AVMP employing an appropriate algorithm based on the current value for an output signal from a control tool and the measured current value for an influencing parameter.

\section{Literature review and problem statement}

As it is known [1], an additional measurement error of a control tool denotes a component of the error, which occurs as a result of deviation in any influencing magnitude from its normal value or because it leaves the region of normal values. A working range of values for every influencing magnitude, within which one regulates additional errors or change in the readings from a measurement tool (control) is indicated in the specifications separately for any tool. It is typically assumed that AME is distributed evenly along the entire working region of change in every influencing magnitude, and this error is rated over a certain predefined part of this region. At the maximal permitted deviation of an influencing magnitude, AME is determined from multiplying the rated AME by the degree of deviation in an influencing magnitude from the rated value. The main disadvantage of the method is that it does not take into consideration the current value for an output signal from a control tool and the non-linearity of its static characteristics both on a change in the influencing and measured parameters. Papers [2, 3] consider the impact of change in the coefficient of conversion for a control tool when it is exposed to the action of deviation in an influencing parameter on the rated value; the authors also describe an algorithm for determining a correction to the measurement result. The proposed algorithm is implemented in the following stages:

- calibration of thermometers at a calibrating laboratory under normal conditions and determining its conversion function;

- determining a conversion function under working conditions when a thermometer takes several values of temperature, reproduced a reference transmitter under working conditions;

- computation of deviations in the values for temperature, determined by a conversion function, established under normal conditions and defined for actual temperature under working industrial conditions; determining corrections at several fixed points of temperature;

- determining a temperature dependence of corrections for the output signal from a thermometer according to industrial conditions by interpolating the values for corrections;

- introduction of corrections to temperature values determined by a calibrated thermometer.

A positive aspect of [2] is that the authors established a functional dependence of correction between the deviation in an influencing parameter on the rated value, which is nonlinear, as well as the dependence of the value for a correction on the measured parameter. The main disadvantage of work [3] is the complexity of the algorithm for computing a correction and its independence from the current value for a measured parameter.

Papers $[4,5]$ proposed a CFD modeling method to study AME. In accordance with the method described in [4], a corrective factor is determined, which changes the conversion coefficient at the current value for the output signal from a control tool. A positive aspect of paper [5] is that based on the known influencing structural parameters, a corrective factor is determined for any converting link in a control tool. The value of corrective factor is introduced to an appropriate algorithm, which computes the actual value for a measured parameter.

The main disadvantage of the method is the complexity of computing a corrective factor for control tools with nonlinear static characteristics, while the correction is introduced not to the result of current measurement but to a conversion coefficient. Paper [6] shows that a variety of influencing parameters cause a change in conversion coefficients and it is proposed, to determine AVMP, to perform the calibration of such tools directly under working conditions. The advantage is a high accuracy of AME determination, its independence from the nonlinearity of the static characteristic. The disadvantages of the method include, first, the need to have a reference portable control tool, second, the method is periodic and inapplicable for the current introduction of a correction to the measurement result.

The method of test influences [7] is the most suitable for use in computer-integrated systems of control and management. According to this method, based on the measured current values for influencing parameters one can calculate corrections to a measurement result and correct test programs. The method of test influences is rather complicated, time-consuming when calculating corrections, and it generates only the multiplicative component of a correction to the measurement result and does not account for the influence of a nonlinear one.

In many cases, the output signal from a control tool is oscillatory in nature with different frequency and amplitude of oscillations, and its AME is predetermined by a deviation in 
the influencing parameter from the rated value. To assess the quality of accuracy and the stability of characteristics, which are used to control technological processes and are regulated by normative documents, determining the upper and lower bounds for an output signal is implied, based on formulae [8]

- for the upper bound

$$
U C L_{i}=\mu_{0 i}+z_{(1-\alpha / 2)} \sigma_{i}
$$

- for the lower bound

$$
\begin{aligned}
& L C L_{i}=\mu_{0 i}-z_{(1-\alpha / 2)} \sigma_{i}, \\
& z=\left(x_{o} \cdot m_{o}\right) / \alpha / \sqrt{n},
\end{aligned}
$$

where $\mu_{\mathrm{o} i}, \sigma_{i}$ are the average value and the root mean square deviation, determined based on the results from previous studies into the trend of an output signal; $z_{(1-\alpha / 2)}$ is the coefficient of significance.

In this case, the spread region of permissible values for the resultant vector of the output signal is determined as difference $\mathfrak{R}=U C L_{i}-L C L_{i}$ and the coefficient of significance from formula

$$
z=\left(x_{o} \Delta m_{o}\right) / \alpha / \sqrt{n},
$$

where $x_{\mathrm{o}}$ is the average value from a Shewhart control chart [9]; $n$ is statistical sample. Since the task on determining AME refers to two-parametric problems, we suggest estimating stability of the technological process based on Hotelling cards [10], in accordance with which one calculates a correlation coefficient. The latter is counted as a result of the current values for an output signal. The method is complicated, it refers to statistical methods, requires a large volume of research and cannot be used for the automatic introduction of a correction to the result of current measurements.

One can see from the results of analysis that AME are determined based on difference in the readings of control tools at normal and current values for influencing parameters. In this case, AME are examined, typically, for a particular control tool, while AVMP is determined from the algebraic sum of the current value for a measured signal and AME. If the current value for a measured parameter is known, then AME should be calculated based on a relevant procedure, which in many cases is imperfect. In almost all cases, AME for a working range of change in an influencing parameter is determined based on the linear principle. In most cases, the dependence of AME on change in an influencing parameter is nonlinear, which leads to the emergence of nonlinear components of an error, whose determining is a rather complex task. The issue on studying AME is typically associated with determining AVMP; when a control tool is exposed to the action of a variety of internal and external factors the normalized values for AME under operating conditions change in most cases. Therefore, there is a task on determining AVMP based only on the current value for an output signal from a control tool and the measured value for an influencing parameter.

\section{The aim and objectives of the study}

The aim of this work is to investigate additional errors from control tools using an integral functional method.
That would make it possible to determine AME over each polling cycle of a computer-integrated system of control and management and to introduce appropriate corrections to measurement result.

To accomplish the aim, the following tasks have been set:

- to substantiate an integral functional method to study AME from control tools;

- to define the effect of influencing parameters on change in the integrated functionality of a control tool;

- to devise a procedure for calculating the actual values for a measured parameter based on the known value for an output signal from a control tool and an influencing parameter.

\section{Substantiation of an integral functional method to study additional measurement errors from control tools}

The systematization of results allows us to consider that existing approaches to solving a task on determining AME are individual and based on methods that are typical only for specific control tools. Such approaches make it possible to determine AME only when the metrological characteristics of control tools are known. As a rule, control tools are described by the experimental-statistical or deterministic methods, which do not make it possible to derive objective mathematical models of AME distribution both over a measurement range and over a working range of change in the influencing parameter. In addition, most methods do not take into consideration a correlation connection between the measured and influencing parameters, which can be significant and change the output signal from a control tool as shown in Fig. 1.

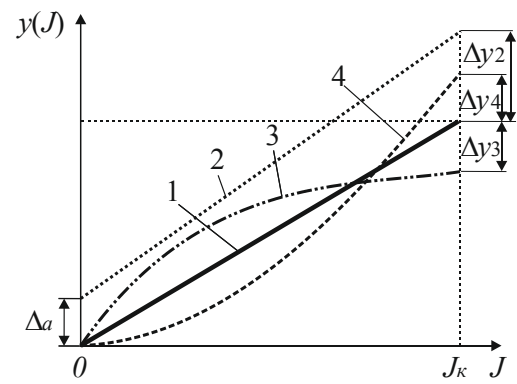

Fig. 1. Dependence of output signal from a control tool at the deviation of an influencing parameter: 1 - graded static characteristic; 2, 3, 4-current static characteristics at the deviation of an influencing parameter from the normalized value linear, exponential, parabolic, respectively)

The measuring range is limited to zero and end $J_{k}$ value for a measured parameter and is stable, established at calibration of the control tool. When an influencing parameter deviates from the rated value, the output signal from a control tool may change in proportion to a change in the measured parameter, or disproportionately. In this case, at the end of the measurement range one observes absolute errors, respectively, $\Delta y_{2}, \Delta y_{3}$ and $\Delta y_{4}$.

The deviation of the influencing parameter from the rated value may cause only the additive component of error $\Delta a$. In this case, there is an issue on AME reduction and optimizing them along the measurement range. To study AME, an integral functional method is proposed, which implies determining a difference between planes under the normalized 
and current static characteristics for a control tool, which occur after the action of an influencing parameter. It is known that as a result of measuring the output signal from a control tool changes from preceding to new ones. Moreover, such a change may be caused both by the deviation in the measured and influencing parameters. If AVMP is known, the absolute value for AME equals

$$
\Delta y(J, z)=y(J, z)-y_{H}\left(J_{\partial}, z_{H}\right),
$$

where $y\left(J_{\partial}, z\right)$ and $y_{H}\left(J_{\partial}, z_{H}\right)$ are the current and normalized value for an output signal; $J_{\partial}, J$ are the actual and current value for a measured parameter, respectively; $z_{H}, z$ are the normalized and current value for an influencing parameter, respectively.

When control tools are operated under industrial conditions, AVMP is unknown. Therefore, determining AME is a rather complex task, since a change in the output signal can be caused by both a change in the measured and influencing parameters. In this case, the current value for AME $\Delta y(J, z)$ is a dependent function, simultaneously from two variables - the current value for measured parameter $J$ and for influencing parameter $z$. The actual values for deviation in the basic influencing parameters (for instance, temperature, atmospheric pressure, air humidity, supplied voltage, current frequency, and others) from their normalized values can be determined by measuring them directly. However, one needs to know the manner AME are distributed along the measurement range at a change in the measured parameter. If a change in the influencing parameter causes, along the measurement range, only the additive or multiplicative components of AME, it can be determined rather simply. To this end, it will suffice to know a conversion coefficient $k_{z}$ of the tool along a channel of the influencing parameter. Expand function $y(J, z)$ into a Taylor's series based on variables $J$ and $z$. Consequently, we obtain for AME

$$
\begin{aligned}
& y\left(J_{\partial}, z\right)=y_{H}\left(J_{\partial}, z_{H}\right)+\frac{d y_{H}\left(J_{\partial}, z_{H}\right)}{d z} \Delta z+ \\
& +\frac{1}{2} \frac{d^{2} y_{H}\left(J_{\partial}, z_{H}\right)}{d z^{2}} \Delta z^{2}+\frac{1}{6} \frac{d^{3} y_{H}\left(J_{\partial}, z_{H}\right)}{d z^{3}} \Delta z^{3}+\ldots+ \\
& +\frac{d^{2} y_{H}\left(J_{\partial}, z_{H}\right)}{d J_{\partial} d z} \Delta J_{\partial} \Delta z+\frac{1}{2} \frac{d^{3} y_{H}\left(J_{\partial}, z_{H}\right)}{d J_{\partial} d z^{2}} \Delta J_{\partial} \Delta z^{2}+\ldots .
\end{aligned}
$$

where $y_{H}\left(J_{\partial}, z_{H}\right)$ is the function of static characteristic under the rated value for an influencing parameter $z_{H} ; y_{z}\left(J_{\partial}, z_{H}\right)$ is the function of an output signal from a control tool when changing the measured and influencing parameters; $J_{\partial}$ is the actual value for a measured parameter; $\Delta z$ is the deviation of the influencing parameter from the rated value; $\Delta J_{\partial}$ is the deviation in the measured parameter.

$\mathrm{AME}$ in general is described by the following equation

$$
\begin{aligned}
& \Delta y_{\partial}\left(J_{\partial}, z\right)=\frac{d y_{z}\left(J_{\partial}, z_{H}\right)}{d z} \Delta z+\frac{1}{2} \frac{d^{2} y_{z}\left(J_{\partial}, z_{H}\right)}{d z^{2}} \Delta z^{2}+ \\
& \frac{1}{6} \frac{d^{3} y_{z}\left(J_{\partial}, z_{H}\right)}{d z^{3}} \Delta z^{3}+\ldots+\frac{1}{2} \frac{d^{2} y_{H}\left(J_{\partial}, z_{H}\right)}{d J_{\partial} d z} \Delta J_{\partial} \Delta z+ \\
& +\frac{1}{2} \frac{d^{3} y_{H}\left(J_{\partial}, z_{H}\right)}{d J_{\partial} d z^{2}} \Delta J_{\partial} \Delta z^{2}+\ldots+\frac{1}{6} \frac{d^{4} y_{H}\left(J_{\partial}, z_{H}\right)}{d J_{\partial} d z^{3}} \Delta J_{\partial} \Delta z^{3}+\ldots
\end{aligned}
$$

Derivatives in equation (3) are the conversion coefficients for a control tool. In order to reduce the conversion coefficients to the same dimensionality, we denote:

$$
\begin{aligned}
& k_{\mu}=d y_{H}\left(J, z_{H}\right) / d z, \\
& k_{v 2}=(1 / 2) d^{2} y_{z}\left(J, z_{H}\right) / d z^{2}, \\
& k_{v 3}=(1 / 6) d^{3} y_{z}\left(J, z_{H}\right) / d z^{3}, \\
& k_{J z \mu}=(1 / 2 J \partial) d^{2} y_{H}\left(J, z_{H}\right) / d J d z
\end{aligned}
$$

and

$$
k_{J z v}=\left(1 / 6 J_{\partial}\right) d^{3} y_{H}\left(J, z_{H}\right) / d J d z^{2} .
$$

Equation (3) takes the following form:

$$
\begin{aligned}
& \Delta y_{\partial}\left(J_{\partial}, z\right)=k_{\mu} \Delta z_{\mu}+k_{v 2} \Delta z_{\mathrm{v} 2}^{2}+ \\
& +k_{v 3} \Delta z_{\mathrm{v} 3}^{3}+\ldots+k_{J z \mu} \delta J_{\partial} \Delta z_{\mu}+ \\
& +k_{J z v 2} \delta J_{\partial} \Delta z_{\mathrm{v} 2}^{2}+\ldots+k_{J z v 3} \delta J_{\partial} \Delta z_{\mathrm{v} 3}^{3}+\ldots
\end{aligned}
$$

where $k_{\mu} \Delta z_{\mu}, \quad k_{v 2} \Delta z_{v 2}^{2}, \quad k_{v 3} \Delta z_{v 3}^{3}$ are the multiplicative, nonlinear quadratic and cubic nonlinear components of AME, which are independent from the measured parameter; $k_{J z \mu} \delta J_{\partial} \Delta z_{\mu}, k_{I z v 2} \delta J_{\partial} \Delta z_{v 2}^{2}, k_{J z v 3} \delta J_{\partial} \Delta z_{v 3}^{3}$ are the multiplicative, nonlinear quadratic and cubic nonlinear components of AME, which are both dependent on a change in the measured and influencing parameters; $\delta J_{\partial}=\Delta J_{\partial} / J_{\partial}$ is the relative change in the measured parameter.

In coordinates $J_{\partial} \rightarrow z$ the product $\delta J_{\partial} \Delta z$ is a certain elemental plane $\Delta S$, predetermined by a change in the measured and influencing parameters. Considering the predetermined, we denote $\Delta S_{\mu}=\delta J_{\partial} \Delta z_{\mu}, \Delta S_{v 2}=\delta J_{\partial} \Delta z_{v 2}$, and $\Delta S_{v 3}=\delta J_{\partial} \Delta z_{v 3}$ in equation (4). Consequently, we obtain

$$
\begin{aligned}
& \Delta y_{\partial}\left(J_{\partial}, z\right)=k_{\mu} \Delta z_{\mu}+k_{\mathrm{v} 2} \Delta z_{\mathrm{v} 2}^{2}+ \\
& +k_{\mathrm{v} 3} \Delta z_{\mathrm{v} 3}^{3}+\ldots+k_{J z \mu} \Delta S_{\mu}+ \\
& +k_{J z v 2} \Delta S_{\mathrm{v} 2} \Delta z_{\mathrm{v} 2}+\ldots+k_{J z v 3} \Delta S_{\mathrm{v} 3} \Delta z_{\mathrm{v} 3}^{2}+\ldots
\end{aligned}
$$

where $\Delta S_{\mu}, \Delta S_{v 2}$ and $\Delta S_{v 3}$ are the multiplicative, nonlinear quadratic and cubic nonlinear components in an increment of areas, predetermined by a deviation of the corresponding components of the influencing parameter from the rated value.

Denote in equation (5)

$$
\Delta y_{z}(z)=k_{\mu} \Delta z_{\mu}+k_{\mathrm{v} 2} \Delta z_{\mathrm{v} 2}^{2}+k_{\mathrm{v} 3} \Delta z_{\mathrm{v} 3}^{3}
$$

is AME component, predetermined by a deviation in the influencing parameter from the rated value;

$$
\Delta y_{J z}\left(\delta J_{\partial}, \Delta z\right)=k_{J z \mu} \Delta S_{\mu}+k_{J z v 2} \Delta S_{\mathrm{v} 2} \Delta z_{\mathrm{v} 2}+k_{J z v 3} \Delta S_{\mathrm{v} 3} \Delta z_{\mathrm{v} 3}^{2},
$$

is $\mathrm{AME}$ component, predetermined by a simultaneous change in the measured and influencing parameters. Equation (5) then takes the following form

$$
\Delta y_{\partial}\left(J_{\partial}, z\right)=\Delta y_{z}(\Delta z)+\Delta y_{J z}\left(\delta J_{\partial}, \Delta z\right) .
$$

An important conclusion follows from equation (6) that suggests that AME is the sum of the component, predetermined by a change in an influencing parameter, and the component, proportional to plane $\Delta S_{\mu}\left(\delta J_{\partial}, \Delta z\right)$, limited ton an increase in the measured and influencing parameters (Fig. 2). Since the output signal from a control tool changes both when changing the measured parameter and when the 
influencing parameter deviates from the rated value, then the AME component $\Delta y_{J z}\left(\delta J_{\partial}, \Delta z\right)$ exists always when $\Delta z \neq 0$.

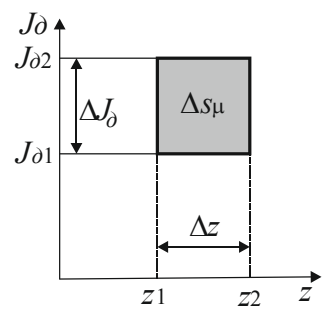

Fig. 2. Graphical explanation of the method of planes

At present, AME is determined provided that the measurement parameter $J_{\partial}=$ const. Under industrial operation of control tools, for example, when measuring the rate of material flows (for instance, a gas flow rate), both the measured and influencing parameters may change at the same time. In such cases, the AME component $y_{J x}\left(\delta J_{\partial}, \Delta z\right)$ can greatly exceed the component $\Delta y_{z}(\Delta z)$. Especially important is to measure the rate of turbulent gas flows. Hence, it follows that for industrial conditions for the measurement of rate of material flows, the most effective is the method of plane, which makes it possible to simultaneously take into consideration both a change in the measured and influencing parameters. Since the static characteristic is a dependence of output signal $y\left(J_{\partial}, z\right)$ y $(\mathrm{J} \partial, \mathrm{z})$ from a control tool on the actual value for measured parameter $J_{\partial}$, then the plane under this characteristic is

$$
d S_{y}\left[f\left(J_{\partial}, z\right)\right]=\int_{J_{\partial 1}}^{J_{\partial 2}} \int_{z_{1}}^{z_{2}} f\left(J_{\partial}, z\right) \mathrm{d} J_{\partial} \mathrm{d} z
$$

where $J_{\partial 1}, J_{\partial 2}$ are the initial and final value for the measured parameter; $z_{1}, z_{2}$ are the initial and final value for the influencing parameter.

If one assumes that for industrial conditions of operating a control tool the range of change in an output signal relative to the actual value for the measured and influencing parameters is linear, then for a single power function, at $f\left(J_{\partial}, z\right)=1$, equation (7) takes the following form

$$
\Delta S_{y}\left[f\left(J_{\partial}, z\right), z\right]=\Delta J_{\partial} \int_{z_{1}}^{z_{2}} f\left(J_{\partial}, z\right) \mathrm{d} z=\Delta J_{\partial} \Delta z .
$$

Taking into consideration that a deviation in the output signal from a control tool $\Delta y\left(J_{\partial}, z\right)=k_{H} \Delta J_{\partial}$, equation (8) is reduced to the following form

$$
k_{H} \Delta S_{y}\left[y\left(J_{\partial}, z\right), z\right]=\Delta y_{z}\left(J_{\partial}, z\right) \Delta z,
$$

where $k_{H}$ is the conversion coefficient along a channel of the measured parameter; $\Delta y_{z}\left(J_{\partial}, z\right)$ is the additional measurement error, caused by a change in influencing parameter $z$.

It follows from equation (9) that AME is fully defined by the plane, which is equal to the AME product multiplied by a deviation $\Delta z$ in the influencing parameter from the rated value. Since $\Delta z=z-z_{H}$, where $z, z_{H}$ are the current, to be measured, and the normalized values for an influencing parameter, respectively, then in order to determine AME, it will suffice to know an increment in the plane $\Delta S_{y}\left[y\left(J_{\partial}, z\right), z\right]$. In order to solve this problem, in this work we have proposed an integral functional method.

\section{Studying additional measurement errors from control} tools using an integral functional method

Integral functional is widely used to optimize the movement of systems of automated control and is described by the following equation

$$
v[x(t)]=\int_{t_{0}}^{t_{1}} F\left[t, x(t), x^{\prime}(t)\right] \mathrm{d} t,
$$

where $x(t)$ is the function of movement over time $t ; F[x(t)$, $\left.x^{\prime}(t)\right]$ is some function that is associated with a motion function over time interval from $t_{0}$ to $t_{1} ; x^{\prime}(t)$ is the derivative from a motion function.

Accept that variable $t$ is the current measured technological parameter $J_{\partial i}$. Then the output signal from a control tool is a function of both the measured parameter $J_{\partial i}$ and the magnitude of deviation $\Delta z$ of the influencing parameter from its normalized value $z_{H}$.

Let the function of the rated output signal $y_{H}=y\left(J_{\partial i}, z_{H}\right)$ be a nominal static characteristic for a control tool, and $y_{z}=y\left(J_{\partial i}, z\right)-$ current. Variation

$$
\Delta y_{\dot{\varepsilon}}\left(J_{\partial}, \Delta z\right)_{H}=y_{i}\left(J_{1 \partial}, z\right)-y_{i}\left(J_{\partial}, z\right)
$$

is a function of deviation of the influencing parameter from the rated value (for example, a deviation in the ambient temperature from the rated $20{ }^{\circ} \mathrm{C}$. Since the measurement range is constant, and derivative $d y_{z} / d z$ is zero only at $z=z_{H}$, then the equation for the integral functional takes the following form

$$
v\left[y_{z}\left(J_{\partial i}, \Delta z\right)\right]=\int_{z_{H}}^{\Delta z} F\left[\Delta z, y\left(J_{\partial i}, \Delta z\right)\right] \Delta J_{\partial i} \mathrm{~d} z .
$$

Since the integrand function $F\left[\Delta z, y\left(J_{\partial i}, \Delta z\right)\right]$ at $z=z_{H}$ equals the plane under the curve $y_{H}=y\left(J_{\partial i}, z_{H}\right)$, and when $z=z_{H}+\Delta z$ - the plane under the curve $y_{z}=y\left(J_{\partial i}, z_{z}\right)$, then their difference is nothing but an increment in the plane between them. A measurement range is stable, while deviations in the influencing parameter from the rated value can vary widely enough. Then a change in the plane between the nominal and current static characteristics would be defined only by the deviation in the influencing parameter. Moreover, for the same measured and influencing parameters the increment in the plane will be the same. Thus, an increment in the plane $\Delta S_{z}\left(\delta J_{\partial i}, \Delta z\right)$ will be the same both at a change in the actual value for the measured and influencing parameters and will be described by the following equations:

- when an influencing parameter deviates from the rated value

$$
v\left[y_{z}\left(J_{\partial i}, \Delta z\right)\right]=k_{\Pi} \int_{-\Delta z_{\partial}}^{\Delta z_{\partial}} \Delta S\left[\Delta y\left(J_{\partial i}, \Delta z\right), \Delta J_{\partial i}\right] \mathrm{d} z,
$$

where $\Delta z_{\partial}$ is the deviation in the influencing parameter when it decreases and increases from the normalized value, respectively; $k_{\Pi}$ is the coefficient, which is equal to the power of the characteristic equation of the integrand function;

- when a measured parameter changes along the measurement range

$$
v\left[y_{z}\left(J_{\partial i}, \Delta z\right)\right]=k_{\Pi} \int_{J_{\partial 0}}^{J_{\partial i}} \Delta S\left[\Delta y\left(J_{\partial i}, \Delta z\right), \Delta z\right] d J_{\partial i},
$$


where $J_{\partial 0}, J_{\partial i}$ are the beginning and end of the measurement range, respectively.

In a general case, the increment in a plane is determined from multiplying a change in the output signal from a control tool by a change in the actual value for the measured or influencing parameter, that is

$$
\Delta S_{J}\left[\Delta y\left(J_{\partial i}, \Delta z\right), \Delta z\right]=\Delta y_{J}\left(J_{\partial i}, \Delta z\right) \cdot \Delta J_{\partial i}
$$

or

$$
\Delta S_{z}\left[\Delta y\left(J_{\partial i}, \Delta z\right), \Delta z\right]=\Delta y_{z}\left(J_{\partial i}, \Delta z\right) \cdot \Delta z
$$

where $\Delta y_{J}\left(J_{\partial i}, \Delta z\right), \Delta y_{z}\left(J_{\partial i}, \Delta z\right)$ is the change in an output signal, predetermined by an increase in the measured and influencing parameters, respectively.

Equations (14) and (15) show that

$$
\Delta y_{J}\left(J_{\partial i}, \Delta z\right)=\Delta y_{z}\left(J_{\partial i}, \Delta z\right)
$$

when $\Delta z=k_{J} \Delta J_{\partial i}$, where $k_{j}$ is a proportionality coefficient. For a linear nominal static characteristic, the output signal

$$
y\left(J_{\partial i}, z\right)=y_{H}\left(J_{\partial i} z_{H}\right)-\delta y_{z}\left(J_{\partial \imath} z\right)=k_{H} J_{\partial i}-k_{z} \Delta z
$$

where $J_{\partial i}, z_{H}$ are the actual value for the measured and nominal values for an influencing parameter, respectively.

If a measurement range starts at zero, then, considering (16), equation (13) takes the form

$$
v\left[y\left(J_{\partial \imath}, \Delta z\right)\right]=k_{\Pi}\left[\int_{0}^{J_{\partial i}}\left(k_{H} J_{\partial i}-k_{z} \Delta z\right) \mathrm{d} J_{\partial i}\right] .
$$

Rewrite equation (17) in the following form

$$
v\left[y\left(J_{\partial i} \Delta z\right)\right]=k_{\Pi 1} \int_{0}^{J_{\partial i}} k_{H} J_{\partial t} d J_{\partial i}-k_{\Pi 2} \int_{0}^{J_{\partial i}} k_{z} \Delta z \mathrm{~d} J_{\partial i}
$$

Since the integrand function of the first component of equation (18) is of second order, then the coefficient $k_{\Pi 1}=2$. The integrand function of the second component of this equation is of first order, then the coefficient $k_{\Pi 1}=2$. Then, upon integration, we obtain the equation for the integral functionality in the form

$$
v\left[y\left(J_{\partial i}, \Delta z\right)\right]=k_{H} J_{\partial i}^{2}-k_{z} J_{\partial} \Delta z
$$

The integral functional is a product of multiplying the output signal by the actual value for the measured technological parameters, that is

$$
v\left[y\left(J_{\partial i}, \Delta z\right)\right]=y\left(J_{\partial i}, \Delta z\right) J_{\partial i} .
$$

And since the calibration of a control tool is performed in the units for measuring a measured parameter, then $y\left(J_{\partial i}\right.$, $\Delta z)=J_{B}$, where $J_{B}$ is the value for an output signal based on the control tool's scale. Considering the above, equation (19) takes the following form: $J_{B} \cdot\left(k_{H} J_{\partial i}\right)=k_{H} J_{\partial i}^{2}-k_{z} J_{\partial i} \Delta z$.

Or the measured value for a measured parameter

$$
J_{B}=J_{\partial i}-\left(k_{z} / k_{H}\right) \Delta z \text {. }
$$

Since the absolute value for deviation in the influencing parameter $\Delta z=z_{H}-z=z_{H} \delta_{z}$, where $z_{H}, z$ are the normalized and current value for an influencing parameter, respectively, and $\delta_{z}=\Delta z / z_{H}$ is its relative deviation, then AVMP is determined from formula

$$
J_{\partial i}=J_{B} \pm z_{H}\left(k_{z} / k_{H}\right) \delta z .
$$

One can see from (21) that for a linear static characteristic, the equation for AME takes the form

$$
\Delta J_{z}=z_{H}\left(k_{z} / k_{H}\right) \delta z
$$

Analysis of equation (22) reveals that AME does not depend on the measured parameter and is proportional to a deviation in the influencing parameter from the rated value. Coefficient $k_{z}$ and $k_{H}$ are as a rule known and are established when testing the prototypes of control tools at an enterprise. Thus, one can see from (21) that the actual value for a measured technological parameter can be determined based on its known measured value and the current value for the influencing parameter. Of practical interest is the task on determining AME when a measured parameter does not change, and there is a deviation in the influencing parameter from the rated value. For this case, equation (12) is recorded in the following form

$$
v\left[y\left(J_{\partial \vartheta} \Delta z\right)\right]=k_{\Pi}\left[\int_{0}^{\Delta z_{z}}\left(k_{H} J_{\partial i} \pm k_{z} \Delta z\right) \mathrm{d}\left(k_{z} z\right)\right] .
$$

where $\Delta z_{\partial}$ is the permissible deviation in an influencing parameter from the rated value.

Equation (23) is rewritten in the following form

$$
v\left[y\left(J_{\partial \vartheta} \Delta z\right)\right]=k_{\Pi 1} \int_{0}^{\Delta z_{\partial}} k_{H} J_{\partial \iota} \mathrm{d}\left(k_{z} z\right) \pm k_{\Pi 2} \int_{0}^{\Delta z_{\partial}} k_{z} \Delta z \mathrm{~d}\left(k_{z} z\right) .
$$

Upon integrating equation (24) based on a change in the influencing parameter $\Delta z$, and taking into consideration $k_{\Pi 1}=1$ and $k_{\Pi 2}=2$, we obtain

$$
v\left[y\left(J_{\partial \vartheta} \Delta z\right)\right]=\left(k_{H} J_{\partial i}\right)\left(k_{z} \Delta z_{\partial}\right) \pm k_{z}^{2} \Delta z_{\partial}^{2} .
$$

In this case, two variants are possible. The first parameter implies that the integral functional is a plane between a change in the output signal from a control tool and the measured parameter, that is, $v\left[y\left(J_{\partial i}, \Delta z\right)\right]=\left(\Delta J_{z}\right)\left(k_{H} J_{\partial i}\right)$. The second variant implies that the integral functional is a plane between an output signal from a control tool and a deviation in the influencing parameter from the normalized value $y\left(J_{\partial i}, \Delta z\right)=k_{H} J_{\partial i} \Delta z$.

For the first variant:

$$
\left(\Delta J_{z}\right) \cdot\left(k_{H} J_{\partial i}\right)=\left(k_{H} J_{\partial i}\right)\left(k_{z} \Delta z_{\partial}\right)+k_{z} \Delta z_{\partial}^{2} .
$$

Since $\Delta J_{z}=J_{\partial i}-J_{B}$, equation (26) is reduced to the following equation of second order

$$
J_{\partial i}^{2}-J_{\partial i}\left(J_{B}+k_{z} \Delta z_{\partial}\right)+\frac{k_{z}}{k_{H}} \Delta z_{\partial}^{2}=0
$$

We find the equation for calculating AVMP from (27) 


$$
J_{\partial i}=\frac{1}{2}\left(J_{B}+k_{z} \Delta z_{\partial}\right)\left[1+\sqrt{1-\frac{4 k_{z} \Delta z_{\partial}^{2}}{k_{H}\left(J_{B}+k_{z} \Delta z_{\partial}\right)^{2}}}\right] .
$$

For the second variant, when the integral functional $y\left(J_{\partial i}, \Delta z\right)=k_{H} J_{B} \cdot k_{z} \Delta z$, we obtain from equation (25)

$$
J_{\partial i}=J_{B}+k_{z} \Delta z_{\partial} .
$$

Comparing equations (28) and (29), we see that the first variant makes it possible to evaluate the linearity of an actual static characteristics, predetermined by a deviation in the influencing parameter from the rated value. In most cases, the ratio $k_{z} / k_{H}<<1$. Then one can accept that the ratio $4 k_{z} \Delta z_{\partial}^{2} / k_{H}\left(J_{B}+k_{z} \Delta z_{\partial}\right)^{2}<<1$ and it can be neglected.

\section{Discussion of results from studying additional measurement errors using an integral functional method}

In laboratory practice, AME is determined by the method of comparing the output signal from a control tool to reference, and under actual conditions - based on its measuring scale. To determine AVMP $J_{\partial i}$, one needs to know both the measured value $J_{B i}$ and error $\Delta J_{B i}$, which depends on a change in any influencing parameter. For the case when $J_{\partial i}=$ const and the conversion coefficient $k_{z}$ along the channel of an influencing parameter's effect is known AME is determined from formula $\Delta J_{B i}=k_{z}\left(z_{B}-z_{H}\right)$, where $z_{B}$ is the measured value for the influencing parameter, and is introduced in the form of a correction to the measurement result. Such a method to improve the accuracy of measurement is approximate and does not make it possible to take into consideration the impact of nonlinear components of additional error. In addition, it does not make it possible to define AVMP under a nonlinear dependence on the output signal and the influencing parameter. This is especially true when measuring a technological parameter at a simultaneous change in both the measured and influencing parameters.

An integral functional method simultaneously relates such basic parameters as the output signal from a control tool, AVMP, and the influencing parameter. This gives an opportunity to derive appropriate mathematical models, which make it possible to determine AVMP and AME based on the known values for an output signal and the influencing parameter. As practice shows, AME in most cases are distributed nonlinearly along the measurement range. For practical use, in order to improve the accuracy of control, only the multiplicative component is typically used, since its dependence on a change in the measured and influencing parameters is linear. The advantage of the proposed method is the possibility to determine AVMP based on the current value for an output signal from a control tool and the influencing parameter. The method does not require previous calculation of AME and formation of the corresponding correction. This greatly simplifies processing time and increases accuracy of the measured information. Mathematical models for determining AVMP are general to all control tools and are distinguished by relative simplicity.

The integral functional method is quite simple for implementation in all automated systems of control and management of technological processes both at the stage of their design and at industrial operations. The method makes it possible to simultaneously determine both the actual value for a measured parameter and the value for an additional measurement error. This provides for an opportunity to construct algorithms for triggering the pre-failure alarm system and emergency blocking based both on the current value for a controlled technological parameter and the magnitude for an additional measurement error, which could greatly increase the metrological reliability of systems of control and management. A limitation for the practical application of the integral functional method is the working permissible bounds to change in influencing parameters of control tools. For theoretical studies into control tools, there are no bounds to apply the method.

The further field of research is the use of an integral functional method to study the actual values for a measured parameter for control tools with nonlinear measurement ranges.

\section{Conclusions}

1. It has been shown that AME can be determined and estimated based on a change in the plane under the static characteristic of a control tool, which is limited by a measurement range, and is a product of change in an output signal and the measured parameter. It is demonstrated that an increment in the plane occurs both at a change in the measured parameter and when the influencing parameter deviates from the normalized value.

2. It has been proven that the increment in the plane at a change in the influencing parameter represents an integral functional, which describes an additional measuring error. An increment in the plane is a function of the measured parameter, the output signal from a control tool, and the influencing parameter. This makes it possible not only to determine the actual value for the measured parameter but an additional measuring error as well.

3. A special feature of the integral functional method for studying additional measurement errors is the possibility to determine the actual value for a measured parameter at a simultaneous change in the measured and influencing parameters. This feature of the method is extremely important when evaluating the results from measuring parameters under industrial conditions of operation of control tools.

The integral functional method makes it possible to simultaneously perform the integration of an output signal based on both a change in the measured and the influencing parameters, and to determine the difference in the results of this integration. That enables the construction of analytical filters for improving the accuracy of measured information under oscillatory changes in the output signal from control tools.

\section{References}

1. DSTU 2681-94. Metrolohiya. Terminy ta vyznachennia. Kyiv: Derzhstandart Ukrainy, 1995. 66 p.

2. Petrychenko H., Nazarenko L., Hots N. Metodyka vyznachennia temperaturnoi zalezhnosti popravok dlia zmenshennia diyi vplyvnykh faktoriv na rezultaty vymirennia temperatury za infrachervonym vyprominenniam v umovakh vyrobnytstva // Metrolohiya ta prylady. 2014. Issue 4 (48). P. 8-12. 
3. Calibration of Low-Temperature Infrared Thermometers // MSL Technical Guide 22. 2009. URL: https://pdfs.semanticscholar. org/408a/354c752a4124f68369fa671d93f5acfba7fc.pdf

4. Doslidzhennia pokhybky ultrazvukovykh vytratomiriv za umov spotvorenoi struktury potoku na osnovi CFD-modeliuvannia / Pistun Ye., Matiko F., Roman V., Stetsenko A. // Metrolohiya ta prylady. 2014. Issue 4 (48). P. 13-23.

5. Turkowski M., Szufle ski P. New criteria for the experimental validation of CFD simulations // Flow Measurement and Instrumentation. 2013. Vol. 34. P. 1-10. doi: https://doi.org/10.1016/j.flowmeasinst.2013.07.003

6. Random Number Generation and Testing. URL: http://csrc.nist.gov/groups/ST/toolkit/rng/index.html

7. Kondrashov S., Opryshkina M., Matsak O. Kontrol metrolohichnoho stanu system z neliniynymy pervynnymy peretvoriuvachamy za dopomohoiu testovykh vplyviv // Metrolohiya ta prylady. 2015. Issue 2. P. 33-41.

8. Volodarskiy E., Koshevaya L., Dobrolyubova M. Otsenivanie kachestva mnogoparametricheskogo tekhnologicheskogo protsessa pri korrelyatsii ego pokazateley // Metrolohiya ta prylady. 2017. Issue 5. P. 20-24.

9. ISO \IEC 17025-2005. General requirements for the competence of testing and calibration laboratories. International Organization for Standardization, 2005.

10. Montgomery D. C. Introduction to Statistical Quality Control. 6th Ed. John Wiley \& Sons, 2009. 754 p.

\begin{abstract}
Робота присвячена питанням визначення оптимальних областей використання двигунної установки для космінних апаратів на низъких навколоземних орбітах. Проведено аналіз запусків космічних апаратів за останні 5 років. В результаті аналізу запусків був обраний тип космічних апаратів, для якого будуть проводитися розрахунки -супутник дистанційного зондування землі на низькій навколоземній орбіті. Була вирішена задача визначення параметрів траєкторії руху космічного апарату, на який впливають зовнішні непостійні сили. За результатами аналізу зовнішнього впливу визначено можливі перспективні області застосування рухових установок космінних апаратів. Виконано порівняльний аналіз з масового критерієм ефективності застосування рухових установок на основі хімічних монокомполентних і електрореактивних двигунів для вирішення завдань підтримки параметрів кругової орбіти протягом тривалого часу.

Для висот орбіт нижие 300 км застосування рухової установки за результатами розрахунків виявилося неефективним через необхідність наявності великого запасу палива на борту і великої необхідної тяги двигуна. Для супутників на кругових орбітах з висотами від 350 до 450 км двигунна установка, яка використовує двигун на ефекті Холла ST-25 SETS, виявилася ефективнішою, ніж хімінна двигунна установка. Застосування хімічних двигунів для підтримки параметрів орбіти висотою вище 500 км буде краще електрореактивних через відносно невелику масу хімічної двигунної установки і достатнього ресурсу роботи двигунів для підтримки параметрів орбіти протягом значного часу.

Були отримані параметри рухової установки, що використовує двигун на ефекті Холла ST-25, для підтримки параметрів орбіт в різних діапазонах висот, сонячної активності і геометричних параметрів супутника. В результаті розрахунків було визначено необхідний ресурс роботи і запас палива для підтримки параметрів орбіти.

Отримані результати розрахунків можуть бути використані при розробці нових супутників і модифікації супутникових платформ

Ключові слова: динаміка польоту, низъкі орбіти, електрореактивний двигун, монокомпонентний двигун, підтримання орбіти
\end{abstract}

\section{口}

At the stage of design, it is important to select the proper type of engine for a satellite since many parameters would depend on a given propulsion system. These parameters include the starting mass and dimensions of a satellite, energy consumption, background radiation, working temperatures, and others.

Electronic database [1] contains basic characteristics for the satellites launched as of April 2018. Table 1 summarizes the distribution of satellites for orbits, which was

Different orbits and missions necessitate maintaining and adjusting the orbit. 